\title{
Fc Receptor-Like Protein 1
}

National Cancer Institute

\section{Source}

National Cancer Institute. Fc Receptor-Like Protein 1. NCI Thesaurus. Code C117130.

Fc receptor-like protein 1 ( 429 aa, $\sim 47 \mathrm{kDa}$ ) is encoded by the human FCRL1 gene. This protein may be involved in B-cell immune functions. 